\title{
Penyingkapan Diri Pasangan Lesbian di Instagram (Studi Tentang Pandangan Generasi Z pada Akun @just.yumi)
}

\author{
Anastasia Cahyadi ${ }^{1}$, Suzy S. Azeharie 2* $^{*}$ \\ ${ }^{1}$ Fakultas Ilmu Komunikasi, Universitas Tarumanagara, Jakarta \\ Email: anastasia.915180029@stu.untar.ac.id \\ ${ }^{2}$ Fakultas Ilmu Komunikasi, Universitas Tarumanagara, Jakarta* \\ Email: suzya@fikom.untar.ac.id
}

Masuk tanggal: 15-12-2021, revisi tanggal: 06-01-2022, diterima untuk diterbitkan tanggal: 16-01-2022

\begin{abstract}
As social beings, humans have a desire to create interpersonal relationships and communication. Interpersonal communication is also often created in the use of social media. However, this can lead to the merging of private space with public space so that private activities can be disseminated, including sexual orientation. One person who dares to reveal her sexual orientation is Yumi. In the @just.yumi account, she shows a lesbian relationship with her girlfriend. For this reason, this study wants to know the views of Generation $Z$ on self-disclosure of lesbian couples on Yumi's Instagram account. The theory used in this research are interpersonal communication and self-disclosure. The author uses a qualitative research approach with a case study method. The research data were obtained through interviews with six sources and one expert resource, simple surveys, documentation and literature studies. The results showed that Generation $Z$ didn't mind with Yumi's content. According to them it is a right and freedom of expression. However, the majority of generation $Z$ also said that Yumi's content could have a negative impact on Instagram users.
\end{abstract}

Keywords: generation Z, lesbian, self-disclosure

\begin{abstract}
Abstrak
Sebagai makhluk sosial, manusia mempunyai keinginan untuk menciptakan hubungan dan komunikasi interpersonal. Komunikasi interpersonal ini juga sering tercipta dalam penggunaan media sosial. Namun hal ini dapat menyebabkan bersatunya ruang pribadi dengan ruang publik sehingga kegiatan yang bersifat pribadi dapat disebarluaskan, termasuk mengenai orientasi seksual. Salah satu orang yang berani menyingkapkan orientasi seksualnya ialah Yumi, dalam akun @just.yumi, di mana pemilik akun memperlihatkan hubungan lesbian dengan pasangannya. Untuk itu penelitian ini ingin mengetahui pandangan generasi $\mathrm{Z}$ pada penyingkapan diri pasangan lesbian dalam akun Instagram. Teori yang digunakan dalam penelitian ini adalah teori komunikasi interpersonal dan penyingkapan diri. Penulis menggunakan pendekatan penelitian kualitatif dengan metode studi kasus. Data hasil penelitian didapatkan melalui wawancara dengan enam narasumber dan satu narasumber ahli, survei sederhana, dokumentasi serta studi kepustakaan. Hasil penelitian menunjukkan bahwa generasi $\mathrm{Z}$ tidak mempermasalahkan konten Yumi karena dinilai sebagai hak dan kebebasan berekspresi. Namun mayoritas generasi $\mathrm{Z}$ juga mengatakan bahwa konten Yumi bisa berdampak negatif pada pengguna Instagram.
\end{abstract}

Kata Kunci: generasi Z, lesbian, penyingkapan diri 


\section{Pendahuluan}

Sebagai makhluk sosial, manusia tidak bisa terlepas dari hubungan dan komunikasi interpersonal. Komunikasi interpersonal ini juga sering tercipta dalam penggunaan media sosial. Media sosial menurut Angie Schottmuller (Susanto, 2017) merupakan saluran komunikasi atau alat yang dapat digunakan dengan tujuan untuk menyimpan, mengakumulasikan, membagikan, berdiskusi serta memberikan informasi di dalam komunitas daring.

Di sisi lain penggunaan media sosial membawa berbagai dampak pada kehidupan sosial. Primada Qurrota Ayun (Anwar, 2017) menyampaikan, masalah yang timbul dari penggunaan media sosial adalah bersatunya ruang pribadi dengan ruang publik bagi para pengguna. Hal tersebut berakibat pada pergeseran budaya yaitu dalam membentuk identitas diri. Pengguna media sosial tidak segan untuk mengunggah segala kegiatan yang bersifat pribadi guna diberitahukan kepada teman ataupun kerabat di akun media sosial.

Dampak tersebut juga terjadi di Instagram. Instagram juga menjadi salah satu sarana untuk penyingkapan diri. Penyingkapan diri menurut Johnson (Hediana dan Winduwati, 2019) adalah membagikan masa lalu yang dilewati dan menceritakan persepsi terhadap hal yang pernah dikatakan atau dilakukan serta perasaan pada berbagai kejadian yang baru dilalui kepada orang lain.

Penyingkapan diri yang dilakukan di Instagram juga beragam. Salah satu yang menarik perhatian adalah penyingkapan diri dari beberapa individu yang cukup dikenal mengenai orientasi seksual mereka sebagai bagian dari kelompok lesbian, gay, biseksual, transgender dan queer.

Salah satu pengguna Instagram yang cukup terkenal seperti Yumi Kwandy, melakukan penyingkapan diri sebagai kelompok LGBTQ pada Instagram. Yumi merupakan seorang model kelahiran Makassar, 30 November 1996. Namanya mulai dikenal publik ketika ia mengikuti acara Indonesia's Next Top Model. Eksistensi Yumi semakin menguat saat masyarakat mengetahui bahwa dirinya menjalin hubungan dengan seorang disc jockey perempuan bernama Chika Kinsky. Dalam akun Instagram miliknya, @just.yumi yang telah terverifikasi dan memiliki 102.000 followers, Yumi tidak ragu membagikan kemesraan serta momen bahagia bersama sang pacar. Dari 20 Juni 2014 hingga 14 September 2021, terdapat 40 unggahan dari 371 unggahan yang memperlihatkan kebersamaan Yumi dan Chika sebagai pasangan lesbian.

Gambar 1. Unggahan Pertama Kebersamaan Yumi dan Chika
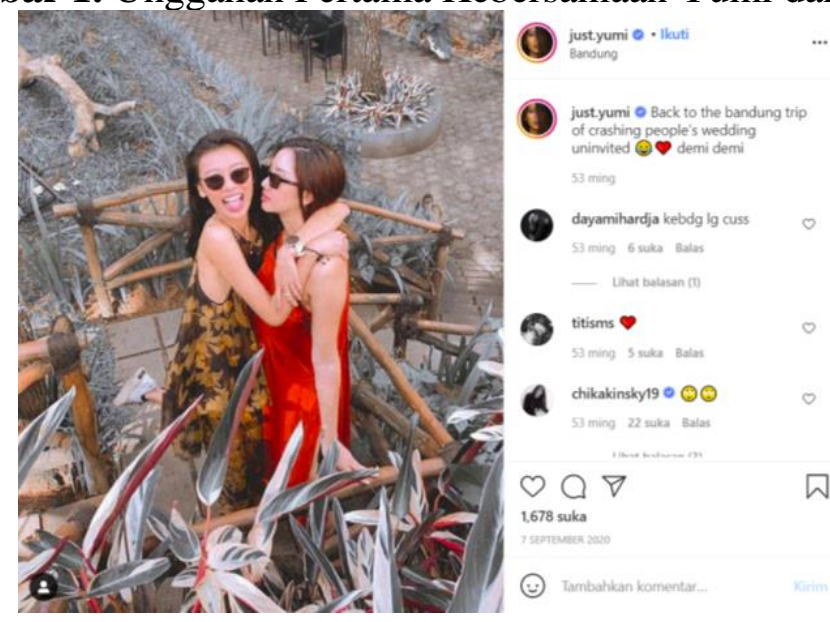

Sumber: Instagram/just.yumi 
Penyingkapan diri ini tentunya menimbulkan beragam pandangan. Tidak terkecuali pada generasi Z sebagai pengguna aktif media sosial. Menurut Business Insider (Arnani, 2021), generasi Z yang lahir pada tahun 1997-2012 atau disebut Gen $Z$, iGen, atau Centennials yang dibesarkan pada era teknologi, internet, serta media sosial. Hal ini membuat sebagian besar cara berkomunikasi mereka adalah melalui media sosial dan teks. Terlebih lagi, menurut survei Pew Research (Rahmawati, 2021) Instagram, Snapchat, dan TikTok adalah media sosial kegemaran generasi Z.

Dalam penelitian ini, pandangan generasi $\mathrm{Z}$ dianggap penting untuk digali karena beberapa faktor. Pertama, generasi Z merupakan kelompok usia yang mendominasi di Indonesia dengan jumlah 75,49 juta jiwa atau 27,94 persen dari 270,20 juta penduduk Indonesia (Sinaga, 2021). Kedua, generasi Z dibesarkan pada era teknologi sehingga cara berkomunikasi dilakukan melalui pemanfaatan media sosial atau dengan kata lain mereka sudah paham dan tidak asing dengan media sosial. Ketiga, salah satu media sosial yang digemari oleh generasi $\mathrm{Z}$ adalah Instagram yaitu aplikasi yang digunakan oleh Yumi dan pasangannya dalam menyingkapkan diri sebagai pasangan lesbian.

Berdasarkan penjabaran tersebut, penulis melakukan penelitian dengan tujuan mengetahui pandangan generasi $\mathrm{Z}$ pada penyingkapan diri pasangan lesbian pada akun Instagram. Oleh karena itu, penulis akan melakukan penelitian yang berjudul "Pandangan Generasi Z pada Penyingkapan Diri Pasangan Lesbian (Studi pada Akun Instagram @just.yumi)".

\section{Metode Penelitian}

Penelitian ini menggunakan pendekatan kualitatif dengan metode studi kasus. Penelitian kualitatif sifatnya deskriptif dan cenderung menerapkan analisis dengan pendekatan induktif. Proses dan pemaknaan dari sudut pandang subyek lebih diperlihatkan dalam penelitian ini (Sugiarto, 2015). Sedangkan studi kasus menurut Bogdan dan Biklen (dalam Mardawani, 2020) adalah pengujian yang spesifik pada suatu latar, seseorang yang merupakan subyek, dan sebuah tempat penyimpanan dokumen atau sebuah peristiwa. Penulis menggunakan pendekatan dan metode ini karena ingin menggali secara mendalam mengenai pandangan generasi $\mathrm{Z}$ pada penyingkapan diri pasangan lesbian di akun Instagram @just.yumi.

Dalam penelitian ini subjek penelitiannya ialah generasi $\mathrm{Z}$ dan objek penelitiannya ialah penyingkapan diri pasangan lesbian dalam akun Instagram @just.yumi. Metode pengumpulan data dilakukan dengan wawancara, survei sederhana, dokumentasi, serta studi kepustakaan. Penulis melakukan wawancara mendalam dengan enam narasumber yaitu generasi $\mathrm{Z}$ yang berumur 13-24 tahun serta mengikuti akun@just.yumi. Selain itu penulis mewawancarai narasumber ahli untuk memperkuat data. Sedangkan untuk survei sederhana dilakukan melalui Google Forms dan melibatkan 25 responden. Selanjutnya dokumentasi dilakukan oleh penulis untuk mengumpulkan tangkapan layar, foto, dan data lainnya yang diperlukan. Terakhir penulis menggunakan buku-buku dan jurnal penelitian yang berkaitan dengan penelitian untuk melengkapi data-data yang diperlukan.

Dalam penelitian ini penulis menggunakan teknik pengolahan dan analisis data model Miles and Huberman. Menurut Miles and Huberman (dalam Sugiyono, 2013), tahap pengolahan dan analisis data ialah reduksi data, penyajian data, dan penarikan kesimpulan. Penulis melakukan reduksi data untuk pemilihan narasumber, responden serta teori dan informasi yang digunakan. Penyajian data dilakukan dalam bentuk 
naratif, pie chart, dan diagram batang. Setelah itu penarikan kesimpulan akan dilakukan untuk mendapat data yang jelas dan valid. Penulis juga menggunakan teknik triangulasi untuk membandingkan informasi yang ada melalui sumber dan metode yang berbeda yaitu wawancara, dokumentasi, angket dan studi kepustakaan untuk menghasilkan data yang akurat dan terpercaya.

\section{Hasil Temuan dan Diskusi}

Penyingkapan diri menurut Bochner (dalam DeVito, 2011) dapat menyebabkan penolakan pribadi dan sosial. Penyingkapan diri biasanya dilakukan kepada orang yang dipercayai. Individu akan melakukan penyingkapan diri kepada orang yang dianggap akan mendukung penyingkapan dirinya. Akan tetapi orang tersebut mungkin juga menolak penyingkapan diri tersebut.

Berdasarkan survei sederhana yang dilakukan pada 25 responden, sebanyak 21 responden menyatakan bahwa mereka tidak terganggu dengan unggahan Yumi yang memperlihatkan hubungannya bersama pacarnya di akun @just.yumi. Sementara itu empat responden lainnya mereka terganggu dengan unggahan tersebut. Dari data ini terlihat walaupun budaya Indonesia cenderung menolak kehadiran LGBTQ masih ada pengguna Instagram yang terbuka terhadap hal ini dan tidak mempermasalahkan kehadiran Yumi di Instagram. Namun tetap ada beberapa pengguna Instagram yang merasa unggahan Yumi kurang baik untuk ditampilkan.

Diagram 1. Penolakan dari Pengguna Instagram

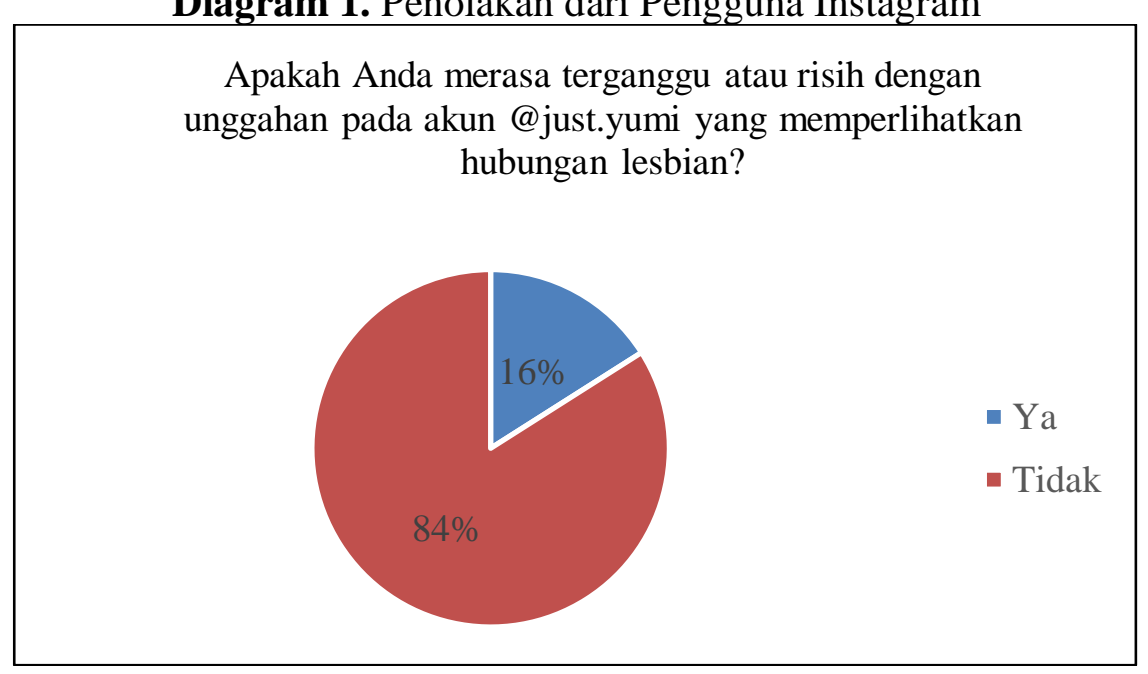

Sumber: Pengolah Data oleh Peneliti

Berdasarkan hasil wawancara dengan enam narasumber melalui platform Zoom pada Oktober lalu, mereka tidak mempermasalahkan unggahan akun @just.yumi. Mereka tidak merasa terganggu ataupun risih dengan unggahan tersebut. Felicia, Christopher, dan narasumber keempat sangat menghargai kebebasan berekspresi dan berpendapat sehingga mereka menganggap konten yang diunggah Yumi hanya memperlihatkan kasih sayang selayaknya pasangan yang sedang menjalani hubungan.

Sedangkan menurut Veronica ia tidak terganggu atau risih dengan unggahan akun@just.yumi karena cara Yumi mengunggah dan bergaya tidak vulgar atau sebebas di luar negeri. Menurutnya unggahan-unggahan tersebut masih dalam batas yang wajar untuk dilihat. 
Narasumber Yuditha juga tidak merasa terganggu dengan unggahan Yumi. Namun ia mengatakan pada awalnya ia cukup kaget karena Yumi berani membuka informasi yang cukup pribadi di media sosial. Ia mengatakan, "Bukan risih sih, gak nyangka aja mereka seberani itu mengumbar hubungan pribadi, seterbuka itu di social media. Tapi kalau dibilang risih gak ya karena itu urusan masing-masing. Kalau misalnya aku risih dengan konten mereka aku juga tinggal gak usah lihat sih" - Yuditha (Batu, 9 November 2021)

Selanjutnya narasumber Intan juga merasa hal itu termasuk normal baginya karena ia merasa telah memiliki pandangan yang luas mengenai kelompok LGBTQ. "Dari aku pribadi juga udah cukup open minded tentang hal-hal seperti itu dan memang gak bisa dipungkirin hal-hal itu juga ada di Indonesia. Jadi dinormalkan saja kalau buat aku pribadi" - Intan (9 November 2021).

Hubungan teori dan konsep yang digunakan dan hasil wawancara serta survei yang dilakukan juga didukung oleh pernyataan narasumber Debora. Menurut Debora respon atau penolakan itu kembali lagi pada setiap individu. Debora berpendapat jika orang yang melihat unggahan akun @just.yumi cukup cerdas, mereka bisa membangun batasan. Batasan ini yang akan menyadarkan orang tersebut untuk menganggap hubungan tersebut bersifat pribadi, hanya antara Yumi dan pasangannya. Dari hal ini, orang tersebut tidak melibatkan kehidupannya pada unggahan atau hubungan mereka. Jadi hanya sebatas mengetahui saja.

Namun mayoritas generasi Z mengakui bahwa unggahan akun @ just.yumi bisa berdampak negatif pada pengguna Instagram. Sifat dasar positif dan negatif menurut Pearson (dalam Zulfa, 2018) adalah hal positif atau negatif yang disingkapkan seseorang mengenai pribadinya karena seseorang dapat memuji atau menjelekkan pribadinya.

Berdasarkan survei sederhana yang telah dilakukan kepada 25 responden, sebanyak 14 responden setuju bahwa unggahan akun @just.yumi dapat membawa dampak negatif pada masyarakat. Sedangkan 11 responden lainnya menganggap unggahan akun @just.yumi memberikan dampak positif bagi masyarakat. Hal ini memperlihatkan bahwa budaya dan nilai masyarakat Indonesia yang menganggap kelompok LGBTQ tidak baik, masih mendominasi. Namun ada juga generasi $Z$ yang telah menerima kehadiran kelompok LGBTQ dan tidak terpengaruh pada konsekuensi yang dihasilkan dari unggahan akun @just.yumi.

Diagram 2. Dampak Unggahan Akun @just.yumi

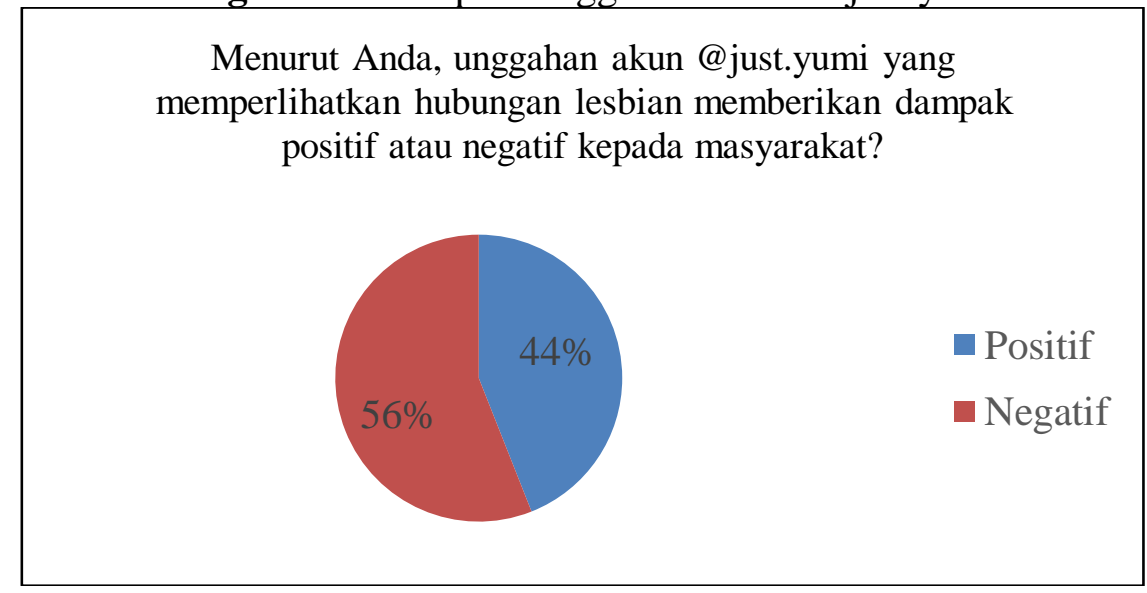

Sumber: Pengolah Data oleh Peneliti 
Berdasarkan wawancara melalui platform Zoom dengan keenam narasumber yang kontra, mereka menyepakati bahwa unggahan akun @just.yumi dapat berdampak negatif. Sisi negatif lebih terlihat jelas karena mayoritas masyarakat Indonesia masih belum menerima keberadaan kelompok LGBTQ. Dari unggahan Yumi, pengikut atau orang yang melihat unggahan Yumi dapat saja meniru atau membuat unggahan yang lebih berani lagi. Terlebih lagi remaja atau anak-anak yang begitu mengidolakan Yumi dan belum cukup diedukasi serta belum memiliki pandangan luas bisa saja menyerap seluruh unggahan akun @just.yumi tanpa dipilah. Akibatnya mereka bisa mengikuti seluruh pilihan Yumi termasuk mengenai orientasi seksualnya.

Namun narasumber Felicia Melody, Christopher Adrianus dan Intan merasa unggahan ini juga dapat berdampak positif. Menurut Felicia, unggahan Yumi dapat merepresentasikan kelompok LGBTQ. Sedangkan menurut Christopher dan Intan, mereka sepakat bahwa unggahan Yumi dapat memperlihatkan kebebasan berekspresi dan berpendapat.

Hubungan teori dan konsep yang digunakan dengan hasil wawancara juga diperkuat dengan pernyataan Debora. Debora mengatakan bahwa sesungguhnya lebih banyak kontra atau sisi negatif dari unggahan Yumi. Hal ini berlaku seandainya, ketika seseorang meniru Yumi. Ia mengatakan bahwa ada beberapa penyebab homoseksualitas yang terjadi karena meniru. Terlebih lagi menurut Debora, remaja sering kali memiliki kiblat atau acuan kepada idolanya. Apapun yang dilakukan idolanya dapat ditiru tanpa dipilah. Untuk itu sebenarnya unggahan seperti ini dapat memengaruhi orang-orang yang tidak bisa mengolah informasi dengan baik dan tidak bisa melepaskan entitasnya. Jadi menurut Debora seharusnya semua orang lebih objektif ketika melihat unggahan ini.

\section{Simpulan}

Pandangan dari mayoritas generasi $\mathrm{Z}$ tidak mempermasalahkan dan tidak merasa terganggu dengan unggahan akun @just.yumi yang memperlihatkan hubungan sejenis. Sebagian besar berpendapat bahwa akun @just.yumi adalah milik Yumi sehingga konten yang diunggah merupakan pilihan dan kebebasan Yumi. Mereka juga menganggap keberanian Yumi yang memperlihatkan hubungan dan orientasi seksualnya di Instagram merupakan bentuk kebebasan berekspresi dan berpendapat. Selama konten yang diunggah tidak vulgar atau berlebihan mereka tidak merasa terganggu.

Namun sebagian dari responden generasi $\mathrm{Z}$ mengakui bahwa konten yang diunggah bisa berdampak negatif. Dampak negatif ini bisa terjadi kepada diri Yumi maupun pengguna Instagram yang melihatnya. Yumi bisa saja mengalami perundungan berupa komentar negatif atau tindakan lainnya yang membuat Yumi tidak nyaman. Mengingat budaya di Indonesia belum terbuka dengan kelompok LGBTQ. Sedangkan dampak negatif untuk pengguna Instagram bisa terjadi ketika penggemar fanatik dan anak-anak yang belum mendapat edukasi yang cukup meniru perilaku Yumi. Selain itu mereka khawatir unggahan Yumi dapat memicu pengguna Instagram membuat konten yang lebih bebas lagi.

Menurut dosen komunikasi Glorya Agustiningsih (2018), pengaruh media menyebabkan adanya perubahan gaya hidup berdasarkan informasi yang diperoleh. Perubahan itu yakni peniruan atau imitasi secara berlebih pada figur yang sedang digandrungi. Biasanya seorang penggemar akan meniru semua yang berkaitan dengan individu yang dikagumi baik dalam hal berpakaian, berpenampilan, potongan 
rambutnya maupun cara berbicara yang mencerminkan diri idolanya. Hal ini cenderung lebih memengaruhi generasi muda. Secara sosio-psikologis, aliran informasi yang terus menerpa akan menyebabkan pengaruh pada perkembangan jiwa, khususnya untuk anak-anak dan remaja.

\section{Ucapan Terima Kasih}

Peneliti mengucapkan terima kasih kepada Fakultas Ilmu Komunikasi Universitas Tarumanagara, narasumber, serta semua pihak yang turut membantu peneliti sehingga penelitian ini dapat diselesaikan.

\section{Daftar Pustaka}

Anwar, Fahmi. (2017). Perubahan dan Permasalahan Media Sosial. Jurnal Muara. 1(1). 137-144.

Arnani, Mela. (2021). Mendominasi Penduduk Indonesia, Mari Mengenal Generasi Z dan Milenial.

<https://www.kompas.com/tren/read/2021/01/22/190400965/mendominasipenduduk-indonesia-mari-mengenal-generasi-z-dan-milenial?page=all $>$ diakses pada tanggal 16 Agustus 2021 pukul 18.50 WIB.

Hediana, Dhiya Fauziani dan Septia Winduwati. (2019). Self Disclosure Individu Queer Melalui Media Sosial Instagram (Studi Deskriptif Kualitatif pada Akun @ kaimatamusic). Jurnal Koneksi. 3(2). 493-500.

Mardawani. (2020). Praktis Penelitian Kualitatif Teori Dasar dan Analisis Data Dalam Perspektif Kualitatif. Sleman: Deepublish.

Rahmawati, Siti Nur. (2021). Instagram, Snapchat, dan TikTok Jadi Media Sosial Favorit Gen Z. <https://tekno.tempo.co/read/1490586/instagram-snapchatdan-tiktok-jadi-media-sosial-favorit-gen-z/full\&view=ok $>$ diakses pada tanggal 16 Agustus 2021 pukul 18.57 WIB.

Sinaga, Shinta NM. (2021). Infografis Gen Z Dominasi Penduduk Indonesia. $<$ https://www.liputan6.com/news/read/4467203/infografis-gen-z-dominasipenduduk-indonesia > diakses pada tanggal 26 September 2021 pukul 19.46 WIB.

Sugiarto, Eko. (2015). Menyusun Proposal Penelitian Kualitatif: Skripsi dan Tesis. Yogyakarta: Suaka Media.

Sugiyono. (2013). Metode Penelitian Kuantitatif, Kualitatif dan R\&D. Bandung: Alfabeta.

Susanto, Eko Harry. (2017). Media Sosial Sebagai Pendukung Jaringan Komunikasi Politik. Jurnal ASPIKOM. 3(3). 379-398. 